\title{
Disruption of Cytoskeletal Structures Mediates Shear Stress-induced Endothelin-1 Gene Expression in Cultured Porcine Aortic Endothelial Cells
}

Toshisuke Morita, Hiroki Kurihara, Koji Maemura, Masao Yoshizumi, and Yoshio Yazaki

The Third Department of Internal Medicine, Faculty of Medicine, University of Tokyo, Tokyo 113, Japan

\begin{abstract}
Hemodynamic shear stress alters the architecture and functions of vascular endothelial cells. We have previously shown that the synthesis of endothelin-1 (ET-1) in endothelial cells is increased by exposure to shear stress. Here we examined whether shear stress-induced alterations in cytoskeletal structures are responsible for increases in ET-1 synthesis in cultured porcine aortic endothelial cells. Exposure of endothelial cells to $5 \mathrm{dyn} / \mathrm{cm}^{2}$ of low shear stress rapidly increased monomeric G-actin contents within 5 min without changing total actin contents. The ratio of $G$ - to total actin, $54 \pm 0.8 \%$ in quiescent endothelial cells, increased to $87 \pm 4.2 \%$ at $6 \mathrm{~h}$ and then decreased. Following the disruption of filamentous (F)-actin into G-actin, ET-1 mRNA levels in endothelial cells also increased within 30 min and reached a peak at $6 \mathrm{~h}$. The F-actin stabilizer, phalloidin, abolished shear stress-induced increases in ET-1 mRNA; however, it failed to inhibit increases in ET-1 mRNA secondary to other stimulants. This indicates that shear stress-induced increases in ET-1 mRNA levels may be mediated by the disruption of actin fibers. Furthermore, increases in ET-1 gene expression can be induced by actin-disrupting agents, cytochala$\sin B$ and D. Another cytoskeleton-disrupting agent, colchicine, which inhibits dimerization of tubulin, did not affect the basal level of ET-1 mRNA. However, colchicine completely inhibited shear stress- and cytochalasin B-induced increases in ET-1 mRNA levels. These results suggest that shear stress-induced ET-1 gene expression in endothelial cells is mediated by the disruption of actin cytoskeleton and this induction is dependent on the integrity of microtubules. (J. Clin. Invest. 1993. 92:1706-1712.) Key words: endothelium • endothelin-1 • shear stress $\bullet$ cytoskeleton • signal transduction
\end{abstract}

\section{Introduction}

Vascular endothelial cells form a continuous monolayer covering the luminal surface of the vascular system and mediate various signals brought by blood flow to underlying tissues including smooth muscle. Hemodynamic shear stress arising from blood flow is one of the major factors that affects endothelial morphology and function. Shear stress alters the shape of endothelial cells and aligns them in the direction of flow in

Address reprint requests to Hiroki Kurihara, The Third Department of Internal Medicine, Faculty of Medicine, University of Tokyo, 7-3-1, Hongo, Bunkyo-ku, Tokyo, 113, Japan. 1993.

Received for publication 10 June 1992 and in revised form 30 April

J. Clin. Invest.

(c) The American Society for Clinical Investigation, Inc.

0021-9738/93/10/1706/07 \$2.00

Volume 92, October 1993, 1706-1712 vitro (1) and in vivo (2, 3). Many studies characterizing cytoskeleton have revealed that endothelial cells reorganize actin filaments (microfilaments) into stress fibers, thick actin filament bundles containing myosin, tropomyosin, and $\alpha$-actinin, under shear stress (4-8). These structural changes are postulated to play a role in endothelial adhesion and integrity against damage imposed by shear stress $(8,9)$.

In addition to these cytoskeletal changes, shear stress influences various functions of endothelial cells. For instance, an increase in flow enhances the release of vasodilators such as endothelium-derived relaxing factor or nitric oxide (NO) (10, $11)$ and prostacyclin $(12,13)$ from endothelial cells. In our previous study, we recognized that the production of endothelin-1 (ET-1), ${ }^{1}$ a potent vasoconstrictor peptide in endothelial cells, is also enhanced at the level of gene expression by shear stress (14). Thus, the production of both vasodilators and vasoconstrictor(s) in vascular endothelial cells is regulated in response to shear stress and may contribute to flow-induced and endothelium-dependent control of local vascular tonus in vivo.

The intracellular mechanism by which shear stress induces ET-1 gene expression in ET-1 gene expression remains unknown. Recently, it has been reported that changes in the cytoskeleton is closely associated with some specific gene expression $(15,16)$. So we hypothesized that cytoskeletal changes may be responsible for ET-1 gene expression in endothelial cells induced by shear stress. To test this hypothesis, we examined changes in actin cytoskeleton as well as ET-1 mRNA and peptide levels under shear stress in cultured endothelial cells and tested the effects of agents altering cytoskeletal structures on shear stress-induced ET-1 gene expression and ET-1 peptide production. Here we present evidence that the disruption of actin cytoskeleton mediates shear stress-induced ET-1 gene expression. In addition, we demonstrate that microtubules may be also involved in this signal transduction pathway.

\section{Methods}

Materials. All culture reagents were obtained from Gibco Laboratories (Grand Island, NY). Phalloidin, cytochalasin B, colchicine, calf thymus DNA (type 1), DNase (type 4), and bovine muscle actin were purchased from Sigma Chemical Co. (St. Louis, MO.) $\left[\alpha-{ }^{32}\right.$ P]dCTP was from Amersham International (Buckinghamshire, UK). All other chemicals were purchased from commercial sources.

Cell Culture. Endothelial cells were isolated from adult porcine thoracic aortas and cultured in DME supplemented with 10\% FBS and standard amounts of penicillin/streptomycin. Cells were incubated at $37^{\circ} \mathrm{C}$ in a humidified atmosphere of $5 \% \mathrm{CO}_{2} / 95 \%$ air. The preparation was characterized by the typical "cobblestone" appearance and staining for Factor VIII antigen. For all experiments, confluent monolayers between 5 and 10 passages were grown in $28.3-\mathrm{cm}^{2}$ culture dishes. $24 \mathrm{~h}$ before experiments, cells were washed twice with PBS and maintained in $3.0 \mathrm{ml}$ of serum-free DME.

1. Abbreviations used in this paper: ET-1, endothelin-1; irET-1, immunoreactive ET-1; TPA, 12-O-tetradecanoyl-phorbol-13-acetate. 
Shear stress apparatus. We used the shear stress-producing coneplate apparatus described by Dewey et al. (1) with some modification. Originally, a stainless steel cone $156 \mathrm{~mm}$ in diameter was placed just above multiple test specimens on a base plate. Each specimen was comprised of a small glass coverslip $12 \mathrm{~mm}$ in diameter onto which endothelial cells had been grown. Rotation of the cone forced the culture medium between the cone and plate to flow azimuthally and produced shear stress on the specimens. To avoid the effects of edge flow at the rim of cone and to apply shear stress to a larger amount of cells we inserted a cone $54 \mathrm{~mm}$ in diameter directly into a $28.3-\mathrm{cm}^{2}$ culture dish (60 $\mathrm{mm}$ in diameter). The whole apparatus was placed in an ordinary $\mathrm{CO}_{2}$ incubator at $37^{\circ} \mathrm{C}$ in $5 \% \mathrm{CO}_{2} / 95 \%$ air. The cone was rotated at 80 $\mathrm{rpm}$ and the calculated shear stress was about $5 \mathrm{dyn} / \mathrm{cm}^{2}$ (17). To confirm the existence of laminar flow on the culture plate, we observed the phenomenon of cell alignment after $24 \mathrm{~h}$.

Measurement of G-actin contents. Monomeric G-actin contents of endothelial cells were determined by the DNase inhibition assay developed by Blikstad et al. (18) with some modifications by Hinshaw et al. (19). $80 \mu \mathrm{g} / \mathrm{ml}$ calf thymus DNA was dissolved in $0.1 \mathrm{M}$ Tris- $\mathrm{HCl}$ ( $\mathrm{pH}$ 7.5), $4 \mathrm{mM} \mathrm{MgSO}_{4}$, and $1.8 \mathrm{mM} \mathrm{CaCl}_{2}$, and filtered. $10 \mathrm{mg} / \mathrm{ml} \mathrm{DNase}$ I was stocked in $0.125 \mathrm{M}$ Tris- $\mathrm{HCl}(\mathrm{pH} 7.5), 5 \mathrm{mM} \mathrm{MgCl} 2,2 \mathrm{mM}$ $\mathrm{CaCl}_{2}, 1 \mathrm{mM} \mathrm{NaN}_{3}$, and $0.1 \mathrm{mM}$ PMSF. Working solutions were prepared by 100 -fold dilution in $20 \mathrm{mM}$ imidazole ( $\mathrm{pH} 7.5$ ), $30 \mathrm{mM}$ $\mathrm{NaCl}$, and $15 \%$ glycerol. Cells were lysed in $500 \mu \mathrm{l} \mathrm{HBSS}$ containing $1 \%$ Triton X-100, $2 \mathrm{mM} \mathrm{MgCl}_{2}, 2 \mathrm{mM}$ EGTA, $0.2 \mathrm{mM}$ ATP, and $0.5 \mathrm{mM}$ PMSF. G-actin contents were determined by mixing $5 \mu$ cell lysate and $5 \mu \mathrm{l}$ DNase solution to $1.5 \mathrm{ml}$ DNA solution followed by time-scanning absorbance at $260 \mathrm{~nm}$. For measurements of total actin, $10 \mu \mathrm{l}$ of guanidine solution (a solution containing $1.5 \mathrm{M}$ guanidine $\mathrm{HCl}, 1 \mathrm{M} \mathrm{NaCH}_{3}$ $\mathrm{CO}_{2}, 1 \mathrm{mM} \mathrm{CaCl}_{2}, 1 \mathrm{mM}$ ATP, and Tris- $\mathrm{HCl}, \mathrm{pH} \mathrm{7.5)}$ was added to each reaction mixture to dissociate filamentous $(F)$-actin. A standard curve was obtained by plotting absorbance at $260 \mathrm{~nm}$ at $120 \mathrm{~s}$ after addition of $0.1-4 \mu \mathrm{g}$ bovine muscle actin. G- and total actin levels were standardized by total cellular protein determined by the BCA protein assay (Pierce Chemical Co., Rockford, IL). Data were expressed as $\mathrm{G}$-actin as a percentage of total actin.

Northern blot analysis. Total cellular RNA was extracted by the LiCl-urea technique (20) from endothelial cells and quantitated by measuring absorbance at $260 \mathrm{~nm}$. RNA samples $(5 \mu \mathrm{g})$ were heat denatured in formamide, electrophoresed through $1.2 \%$ agarose/formaldehyde gels, and transferred to nylon membranes (Hybond N; Amersham) by standard procedures (21). As a probe, we excised $0.8 \mathrm{~kb}$ HindIII-HindIII DNA fragment from porcine ET-1 cDNA clone ppET4 (22). The fragment was labeled with $\left[\alpha-{ }^{32} \mathrm{P}\right] \mathrm{dCTP}$ using a standard random-primed reaction. The specific activity was $1 \times 10^{9} \mathrm{cpm} /$ $\mu \mathrm{g}$. The membranes were hybridized for $24-48 \mathrm{~h}$ at $42^{\circ} \mathrm{C}$ in $50 \%$ formamide, $1 \%$ SDS, $0.98 \mathrm{M} \mathrm{NaCl}, 0.25 \mathrm{mg} / \mathrm{ml}$ salmon sperm DNA, and 1 $\times 10^{6} \mathrm{cpm} / \mathrm{ml}$ of the probe. Membranes were washed twice in $2 \times \mathrm{SSC}$ containing $1 \%$ SDS at $65^{\circ} \mathrm{C}$, twice in $2 \times \mathrm{SSC} / 1 \%$ SDS at $37^{\circ} \mathrm{C}$ and once $0.1 \times \mathrm{SSC} / 1 \% \mathrm{SDS}$ at $37^{\circ} \mathrm{C}$ for $15 \mathrm{~min}$ each, and were then exposed to film (X-OMAT AR; Eastman Kodak, Rochester) with intensifying screens at $-80^{\circ} \mathrm{C}$. The membranes were subsequently rehybridized with ${ }^{32} \mathrm{P}$-labeled $\beta$-actin probe to determine an internal standard of total RNA content. The photographical density of $28 \mathrm{~S}$ and $18 \mathrm{~S}$ ribosomal RNA was also served as an internal control. To quantify ET-1 mRNA levels, we scanned autoradiographs with a laser densitometer (2222-020 UltroScan XL; LKB Instruments, Gaithersburg, MD) running the GelScan software package (2400; LKB Instruments).

ELISA. Immunoreactive ET-1 (irET-1) levels in conditioned media were determined by specific "sandwich" ELISA as described (23). Two monoclonal antibodies, $1 \mathrm{Cl} 0$ and $8 \mathrm{H} 10$, which recognized $\mathrm{NH}_{2}-$ and $\mathrm{COOH}$-terminal sequence of ET-1 respectively, were used for establishment of this assay. The cross-reactivities of ET-2, ET-3, and big ET-1 were 100,1 , and $0 \%$, respectively. The sensitivity of irET-1 measurement was $2.5 \mathrm{fmol} /$ well and the $50 \%$ intercept was $32 \mathrm{fmol} /$ well.

Statistical analysis. All quantitative values of G-actin contents and ET-1 levels were expressed as mean \pm SEM, $n=4-6$. Analysis of variance with Scheffe's test was used to determine significant differences in multiple comparisons. $P<0.05$ was considered significant.

\section{Results}

Shear stress-induced changes in G-actin levels and ET-1 gene expression. We exposed polygonal endothelial cells to low shear stress of $5 \mathrm{dyn} / \mathrm{cm}^{2}$ using the cone-plate apparatus as described in Methods. After $12 \mathrm{~h}$, we observed ellipsoidal endothelial cells aligned in the direction of laminar flow (data not shown). Stress fiber alignment along the longitudinal cellular axes was also revealed by rhodamine-phalloidin staining (data not shown). These changes confirmed that appropriate shear stress produced by laminar flow was imposed on cultured endothelial cells. We used this condition in the following experiments.

To analyze the effect of shear stress on the equilibrial state of actin fiber, we determined G-actin levels in the cytosol of endothelial cells sequentially in the presence of absence of shear stress. In quiescent endothelial cells, the contents of Gand F-actin were $6.4 \pm 0.2$ and $5.4 \pm 0.2 \mu \mathrm{g} / \mathrm{mg}$ of cellular protein, respectively. These values indicated that $54 \pm 0.8 \%$ of total actin existed as depolymerized G-actin. As shown in Fig. 1, exposure of endothelial cells to shear stress resulted in a significant increase in G-actin contents. This increase was detected as early as $5 \mathrm{~min}$ after exposure to shear stress and reached to the peak level at about $6 \mathrm{~h}$. Then G-actin contents decreased and returned to the basal level at $24 \mathrm{~h}$, when stress fiber alignment appeared distinct. Total actin contents were not changed at any points under shear stress.

We also studied the influence of shear stress on the expression of ET-1 gene and the production of ET-1 peptide in endothelial cells. Fig. 2 demonstrates that exposure of endothelial cells to shear stress resulted in an increase in ET-1 mRNA levels $(A)$ and in ET-1 release into culture media $(B)$. The time course of shear stress-induced ET-1 gene expression showed that ET-1 mRNA started to increase within 30 min following the disruption of actin filaments and reached to the maximal levels $6 \mathrm{~h}$ after exposure to shear stress. ET-1 mRNA levels under shear stress declined to the basal level during the subsequent 12-24 h (14). To compare the time courses of G-actin depolymerization and ET-1 mRNA induction by shear stress, we plotted their levels in the same diagram. As shown in Fig. 2 $C$, the onset of shear stress-induced ET-1 gene expression was preceded by that of actin fiber disruption, but the time course of ET-1 gene expression induced by shear stress was essentially

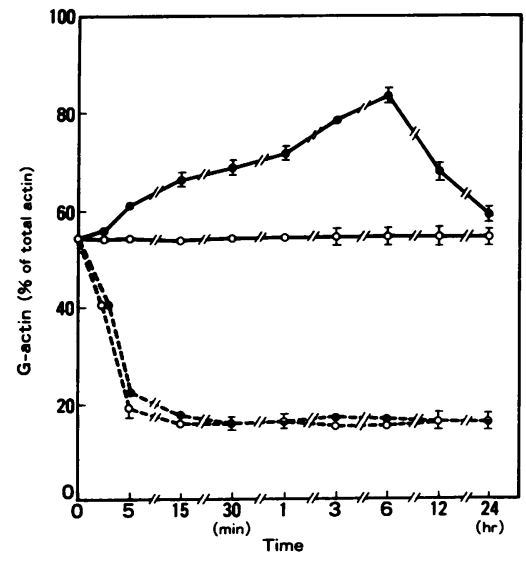

Figure 1. Time course of shear stress-induced changes in G-actin contents in cultured endothelial cells. G-actin contents were shown in endothelial cells in static condition $(0)$ or under shear stress ( 5 dyn/ $\left.\mathrm{cm}^{2}\right)(\bullet)$ in the absence (solid line) or presence (broken line) of phalloi$\operatorname{din}\left(1 \times 10^{-6} \mathrm{M}\right)$, which was added $1 \mathrm{~h}$ before exposure to shear stress. G-actin and total actin levels were mea-

sured by DNase inhibition assay described in Methods. G-actin contents are expressed as a percentage of total actin. Data presented are mean \pm SEM of four separate experiments. 

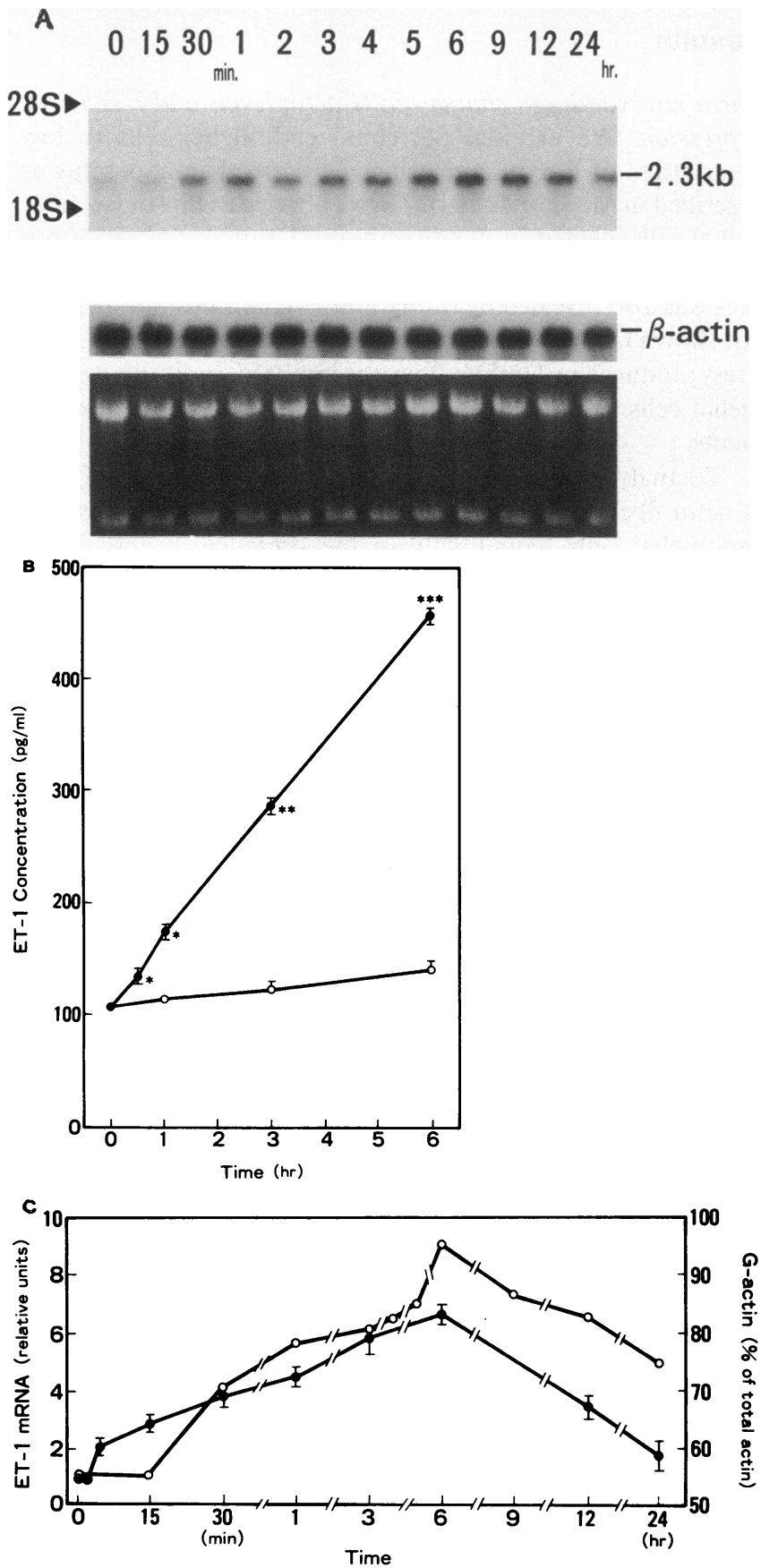

Figure 2. Effect of shear stress on ET-1 mRNA levels in endothelial cells and ET-1 peptide levels in the conditioned media. $(A)$ Confluent endothelial cells were exposed to 5 dyne $/ \mathrm{cm}^{2}$ of shear stress under serum-free condition and harvested for total RNA preparation. Northern blot analysis was performed with $5 \mu \mathrm{g}$ of RNA per lane. In the upper panel, time course of shear stress-induced changes in ET-1 mRNA levels. In the middle panel, signals rehybridized to the $\beta$-actin probe. In the lower panel, $28 \mathrm{~S}$ and $18 \mathrm{~S}$ ribosomal RNA bands. $(B)$ Conditioned media of endothelial cells in static condition $(O)$ or exposed to shear stress $(\bullet)$ were concomitantly collected for the measurement of ET-1 peptide levels by ELISA. $(C)$ Comparison of the time course of changes in G-actin contents and ET-1 mRNA levels. After scanning autoradiographs with a densitometer, the signal density of each RNA sample hybridized to the ET-1 probe was divided by that hybridized to the $\beta$-actin probe. The corrected density for each sample was then divided by that of the untreated static cells and presented in a relative unit plotted against time along with G-actin contents. G-actin contents are expressed as a percentage of total actin. similar to that of shear stress-induced actin fiber disruption. The accumulation rate of ET-1 in media was accelerated within $30 \mathrm{~min}$.

In contrast to the increase in ET- 1 mRNA levels, $\beta$-actin mRNA levels in endothelial cells were not affected by exposure to 5 dyne $/ \mathrm{cm}^{2}$ of shear stress (Fig. $2 A$ ). This result not only rules out the possibility that shear stress-induced ET-1 gene expression might be a nonspecific event, but also indicates that the increase in G-actin content under shear stress is not a consequence of an increase in $\beta$-actin gene expression. The density of $28 \mathrm{~S}$ and $18 \mathrm{~S}$ ribosomal RNA was also unchanged among the lanes (Fig. $2 \mathrm{~A}$ ). The similarity of two time courses for ET-1 gene expression and actin fiber disruption induced by shear stress leads us to examine the relationship of these phenomena.

Inhibition of shear stress-induced ET-1 gene expression and ET-1 synthesis by phalloidin. To elucidate the involvement of actin cytoskeleton in shear stress-induced ET-1 gene expression in endothelial cells, we examined the effect of phalloidin, an agent that stabilizes F-actin by decreasing the rate of actin depolymerization, on ET-1 mRNA under shear stress. Pretreatment with $1 \times 10^{-6} \mathrm{M}$ of phalloidin decreased G-actin contents of endothelial cells in the absence or presence of shear stress (Fig. 1). Phalloidin at the same dose completely inhibited the increase in ET-1 mRNA levels by shear stress (Fig. 3 $A$ ). Shear stress-induced increase in ET-1 levels in culture media was also blocked (Fig. $3 \mathrm{~B}$ ). The dose responses of the inhibitory effects of phalloidin on shear stress-induced ET-1 gene expression and increase in G-actin contents were quite similar (Fig. $3 C$ ). These doses used were not toxic to endothelial cells as indicated by no increased lactic dehydrogenase release (data not shown). Furthermore, ET-1 gene expression induced by $\mathrm{Ca}^{2+}$ ionophore $\mathrm{A} 23187$, phorbol ester $12-O$-tetradecanoylphorbol-13-acetate (TPA), and TGF- $\beta$ was not inhibited by phalloidin (Fig. 4), indicating that the inhibitory effect of phalloidin on shear stress-induced ET-1 gene expression was a specific phenomenon. These results suggest that actin fiber disruption is closely associated with an increase in ET-1 gene expression under shear stress.

Induction of ET-1 gene expression by actin depolymerizing agents. To clarify the coupling of actin fiber disruption with ET-1 mRNA induction, we assessed the effect of cytochalasin $B$, an agent that binds to the end of a growing microfilament causing inhibition of the polymerization of actin, on ET-1 production in endothelial cells. First, we examined the effect of cytochalasin B on G-actin contents at various doses. As shown in Fig. 5, cytochalasin B increased G-actin content in a dosedependent manner, and the response of G-actin to the dose of 1 $\times 10^{-6} \mathrm{M}$ mimicked that to $5 \mathrm{dyne} / \mathrm{cm}^{2}$ of shear stress before 6 h (Fig. 1). As was expected, cytochalasin B enhanced ET-1 gene expression and synthesis of ET-1 peptide by endothelial cells at $1 \times 10^{-6} \mathrm{M}$ (Fig. 6, $A$ and $B$ ). The kinetics of cytochalasin B-induced ET-1 gene expression resembled that of shear stress-induced expression before $6 \mathrm{~h}$. The dose response of cytochalasin B-induced ET-1 gene expression also resembled that of cytochalasin B-induced increase in G-actin contents (Fig. 6 $C)$. Another inhibitor of actin polymerization, cytochalasin $\mathrm{D}$, also induced ET-1 gene expression and ET-1 release in a similar manner (data not shown). In addition, cytochalasin B-induced ET-1 gene expression and synthesis of ET-1 peptide was significantly inhibited by phalloidin (Fig. 6, $A$ and $B$ ). The dose response of the inhibitory effect of phalloidin on cytochalasin B-induced ET-1 gene expression was comparable with that on G-actin levels (Fig. 7), suggesting that these effects of 
A
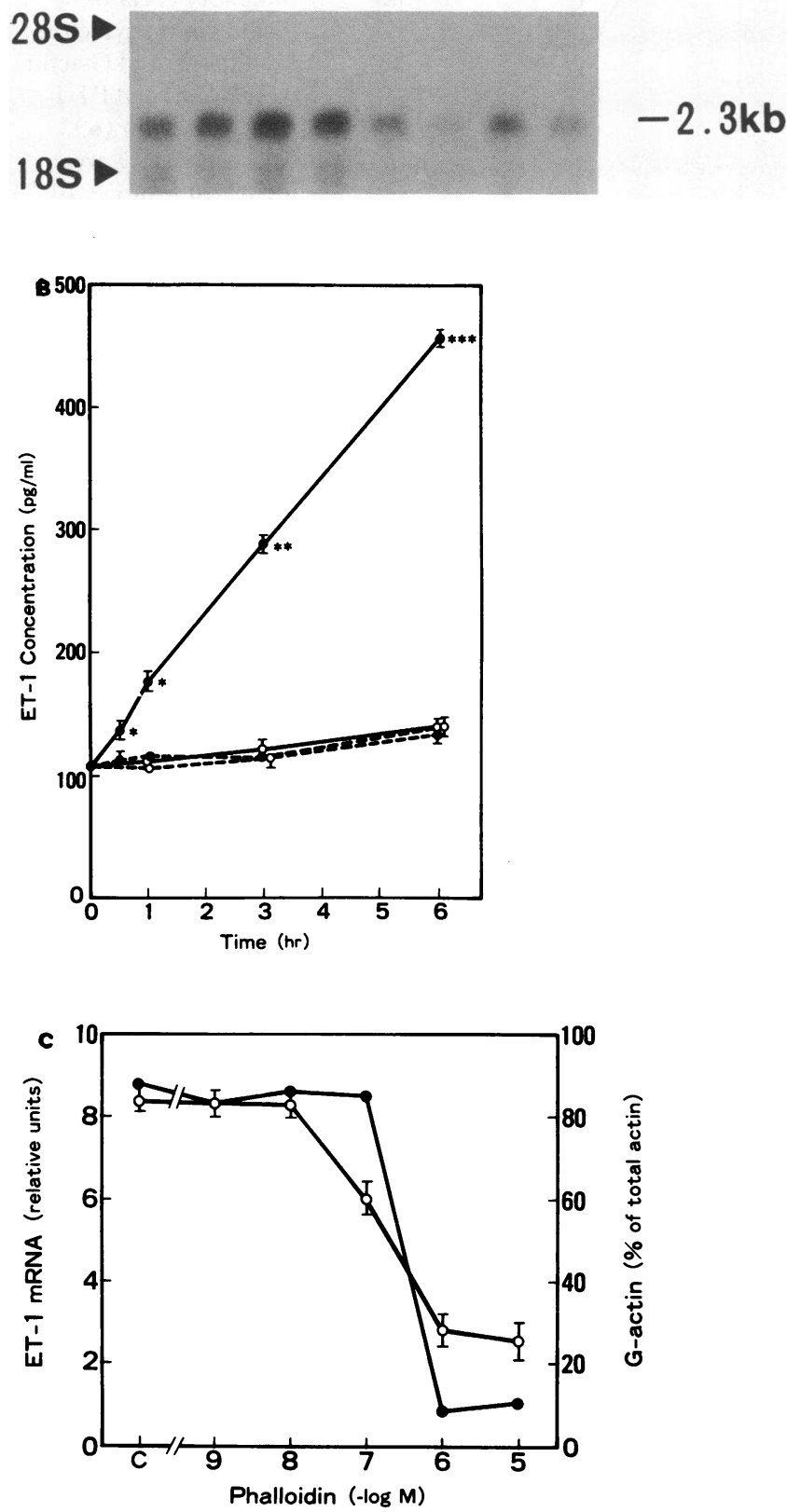

Figure 3. Effect of phalloidin on shear stress-induced ET-1 gene expression in endothelial cells. Treatment with phalloidin $\left(1 \times 10^{-6}\right.$ M) was started $1 \mathrm{~h}$ before exposure of cells to 5 dyne $/ \mathrm{cm}^{2}$ of shear stress. $(A)$ Northern blot analysis was performed with $5 \mu \mathrm{g}$ of total RNA per lane. ET-1 mRNA in static control cells (lane 1); cells exposed to shear stress for $3 \mathrm{~h}$ (lane 2), $6 \mathrm{~h}$ (lane 3 ), or $9 \mathrm{~h}$ (lane 4 ) in the absence of phalloidin; cells exposed to shear stress for $0 \mathrm{~h}$ (lane 5 ), for $3 \mathrm{~h}$ (lane 6 ), $6 \mathrm{~h}$ (lane 7 ), or $9 \mathrm{~h}$ (lane 8 ) in the presence of phalloidin. $(B)$ Conditioned media of endothelial cells in static condition $(0)$ or exposed to shear stress $(\bullet)$ in the absence (solid line) or presence (broken line) of phalloidin $\left(1 \times 10^{-6} \mathrm{M}\right)$ were concomitantly collected for the measurement of ET-1 peptide levels by ELISA. $(C)$ Comparison of the dose-dependent inhibitory effect of phalloidin on shear stress-induced G-actin increase ( $O$ ) and ET-1 gene expression (•). Endothelial cells were exposed to shear stress for $6 \mathrm{~h}$ in the presence of phalloidin. Cells exposed to shear stress without phalloidin served as control (C). G-actin contents are expressed as a percentage of total actin. Each ET-1 mRNA level was quantified and presented in a relative unit as in Fig. $2 C$.

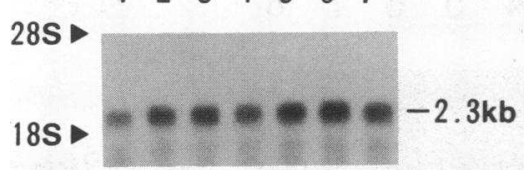

Figure 4. Effect of phalloidin on ET-1 gene expression induced by chemical stimulants. Northern blot analysis was performed with 5 $\mu \mathrm{g}$ of total RNA per

lane. ET-1 mRNA in control cells (lane 1 ); cells treated with $1 \times 10^{-6}$ $\mathrm{M}$ of $\mathrm{A} 23187$ for $3 \mathrm{~h}$ in the absence (lane 2) or presence (lane 3 ) of phalloidin; cells treated with $1 \times 10^{-6} \mathrm{M}$ of TPA for $1 \mathrm{~h}$ in the absence (lane 4) or presence (lane 5) of phalloidin; cells treated with $1 \times 10^{-10}$ $\mathrm{M}$ of TGF- $\beta$ for $3 \mathrm{~h}$ in the absence (lane 6 ) or presence (lane 7) of phalloidin.

cytochalasins were indeed mediated by actin fiber disruption. Taking these observations together, we can postulate that disruption of actin microfilaments mediates the signal from mechanical shear stress to ET-1 gene expression.

Inhibition of shear stress-and cytochalasin B-induced ET1 gene expression by colchicine. We investigated the possible involvement of microtubules, another major component of cytoskeleton, in the regulation of ET-1 gene expression. We treated endothelial cells with colchicine, a microtubuledisrupting agent that binds to $\alpha-\beta$ tubulin dimers and inhibits the polymerization of microtubules, and exposed them to shear stress or cytochalasin B. As shown in Fig. 8, treatment with colchicine did not affect the basal levels of ET-1 gene expression. However, colchicine completely abolished both shear stress- and cytochalasin B-induced ET-1 gene expression in endothelial cells (Fig. $8 A$ ) and release of ET-1 into culture media (Fig. $8 \mathrm{~B}$ ). TGF- $\beta$-induced ET-1 gene expression was not affected by colchicine (data not shown), suggesting that inhibition of shear stress-induced ET-1 gene expression by colchicine was not due to a nonspecific effect.

\section{Discussion}

In this study, we have shown that $(a)$ flow-induced shear stress provoked two distinct phenomena, an increase in G-actin content and an increase in ET-1 gene expression and peptide production, in cultured vascular endothelial cells; $(b)$ the onset of the increase in G-actin content preceded that of the induction

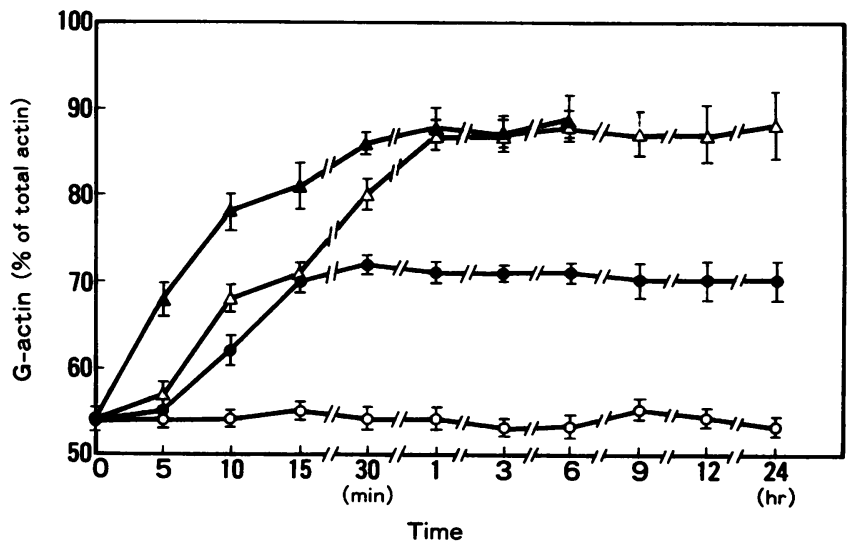

Figure 5. Time course of changes in G-actin contents in endothelial cells treated with various doses of cytochalasin B: $1 \times 10^{-8} \mathrm{M}(0)$, $1 \times 10^{-7} \mathrm{M}(\bullet), 1 \times 10^{-6} \mathrm{M}(\Delta)$, or $1 \times 10^{-5} \mathrm{M}(\triangle)$. G-actin contents are expressed as a percentage of total actin. Data presented are mean $\pm S E M$ of four separate experiments. 

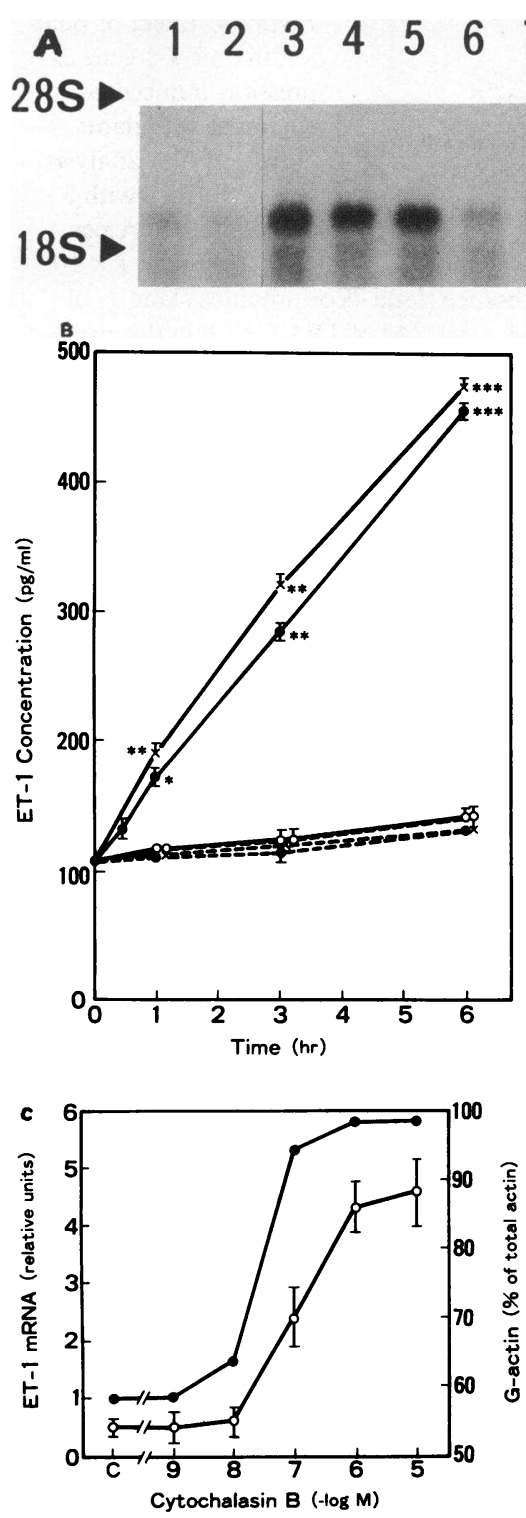

Figure 6. Effect of cytochalasins on ET-1 gene expression in endothelial cells in the absence or presence of phalloidin. $(A)$ Northern blot analysis was performed with $5 \mu \mathrm{g}$ of total RNA per lane. ET-1 mRNA in control cells (lane 1 ); cells preincubated with phalloidin $\left(10^{-6} \mathrm{M}\right)$ for $1 \mathrm{~h}$ (lane 2$)$; cells exposed to cytochalasin $\mathrm{B}\left(1 \times 10^{-6}\right.$ $\mathrm{M}$ ) for $1 \mathrm{~h}$ (lane 3 ), $3 \mathrm{~h}$ (lane 4), or $6 \mathrm{~h}$ (lane 5 ) in the absence of phalloidin; cells exposed to cytochalasin B for $1 \mathrm{~h}$ (lane 6), $3 \mathrm{~h}$ (lane 7 ), or $6 \mathrm{~h}$ (lane 8 ) in the presence of phalloidin. $(B)$ Conditioned media of endothelial cells in static condition $(O)$ or exposed to cytochalasin $\mathrm{B}\left(1 \times 10^{-6} \mathrm{M}\right)(\bullet)$ in the absence (solid line) or presence (broken line) of phalloidin $\left(1 \times 10^{-6} \mathrm{M}\right)$ were concomitantly collected for the measurement of ET-1 peptide levels by ELISA. $(C)$ Comparison of dose response of G-actin increase (O) and ET-1 mRNA induction $(\bullet)$ by cytochalasin B. Endothelial cells were incubated with various doses of cytochalasin B for $1 \mathrm{~h}$. G-actin contents are expressed as a percentage of total actin. Each ET-1 mRNA level was quantified and presented in a relative unit as in Fig. $2 C$.

of ET-1 gene expression and the following time courses for both phenomena were almost the same; $(c)$ shear stress-induced ET-1 gene expression was completely abolished by pretreatment with phalloidin, an agent that stabilizes F-actin; $(d)$ disruption of actin fiber by cytochalasins resulted in the induc-

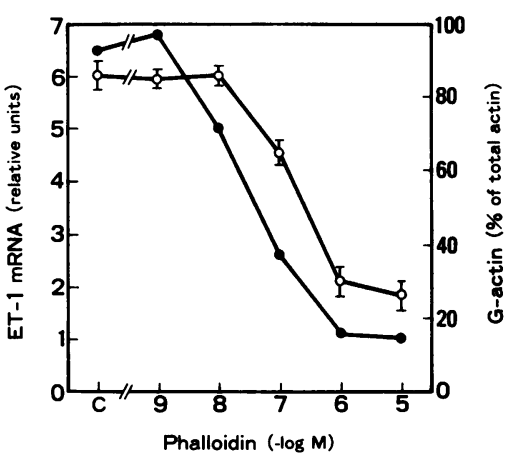

Figure 7. Comparison of the dose-dependent inhibitory effect of phalloidin on cytochalasin B-induced G-actin increase (0) and ET-1 gene expression $(\bullet)$. Endothelial cells were incubated with $1 \times 10^{-6}$ $\mathrm{M}$ of cytochalasin B for $1 \mathrm{~h}$ in the presence of various doses of phalloidin. Cells incubated with cytochalasin B

without phalloidin served as control (C). G-actin contents are expressed as a percentage of total actin. Each ET-1 mRNA level was quantified and presented in a relative unit as in Fig. $2 C$.
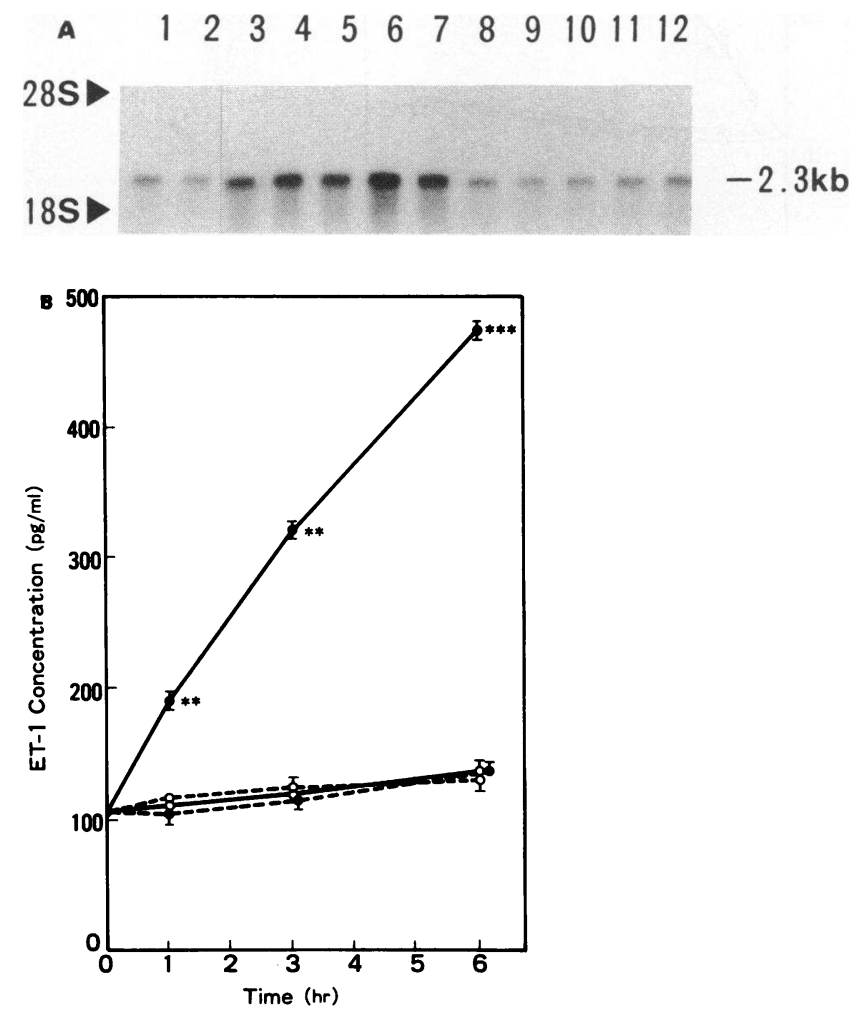

Figure 8. Effect of colchicine on shear stress- and cytochalasin B-induced ET-1 gene expression in endothelial cells. Treatment with colchicine $\left(5 \times 10^{-7} \mathrm{M}\right)$ was started $1 \mathrm{~h}$ before exposure of cells to shear stress or cytochalasin B. $(A)$ Northern blot analysis was performed with $5 \mu \mathrm{g}$ of total RNA per lane. ET- 1 mRNA in control cells (lane 1); cells preincubated with colchicine for $1 \mathrm{~h}$ (lane 2); cells exposed to shear stress $\left(5 \mathrm{dyn} / \mathrm{cm}^{2}\right.$ ) for $3 \mathrm{~h}$ (lane 3 ), $6 \mathrm{~h}$ (lane 4 ), or $9 \mathrm{~h}$ (lane $5)$ in the absence of colchicine; cells exposed to cytochalasin B ( $10^{-6}$ $\mathrm{M}$ ) for $3 \mathrm{~h}$ (lane 6 ) or $6 \mathrm{~h}$ (lane 7) in the absence of colchicine; cells exposed to shear stress for $3 \mathrm{~h}$ (lane 8 ), $6 \mathrm{~h}$ (lane 9), or $9 \mathrm{~h}$ (lane 10) in the presence of colchicine; cells exposed to cytochalasin $\mathrm{B}\left(10^{-6}\right.$ $\mathrm{M})$ for $3 \mathrm{~h}$ (lane 11 ) or $6 \mathrm{~h}$ (lane 12) in the presence of colchicine. $(B)$ Conditioned media of endothelial cells in static condition $(O)$, exposed to cytochalasin $B\left(1 \times 10^{-6} \mathrm{M}\right)(\bullet)$ or exposed to shear stress $\left(5 \mathrm{dyn} / \mathrm{cm}^{2}\right)(\mathrm{l})$ in the absence (solid line) or presence (broken line) of phalloidin $\left(1 \times 10^{-6} \mathrm{M}\right)$ were concomitantly collected for the measurement of ET-1 peptide levels by ELISA. 
tion of ET-1 mRNA; and $(e)$ disruption of microtubules by colchicine completely inhibited shear stress-induced and cytochalasin B-induced ET-1 gene expression. It is also noteworthy that the dose responses of the effects of phalloidin and cytochalasins on ET-1 gene expression were quite similar to those on G-actin contents in endothelial cells. In addition, the doses of phalloidin and cytochalasins used in this study are not more than those used in the previous literatures $(15,24)$. The parallelism between G-actin contents and ET-1 mRNA levels and the relevant doses of these agents argue against the possibility that the effects of phalloidin and cytochalasins were not specific for cytoskeletal changes. These data suggest that shear stress induces ET-1 gene expression via alterations in actin cytoskeletal changes in cultured endothelial cells and this pathway is dependent on the integrity of microtubules.

The shear stress-induced increase in G-actin in endothelial cells seems due to a shift of the equilibrial state between $F$ - and G-actin in favor of G-actin rather than an increase in de novo actin synthesis, because the levels of total actin content and $\beta$-actin mRNA were not changed under exposure to shear stress. It is well known that shear stress causes alterations in the distribution of actin filaments and its reorganization into stress fibers aligned in the direction of flow in endothelial cells (4-8). The initial event of alterations of actin fiber distribution is characterized by the disappearance of peripheral actin fiber rings and the basal foci of radially arranged filaments (7). Under low shear stress as in this study, the formation of longitudinal stress fiber appears distinct at about $12 \mathrm{~h}$ (reference 7 and our unpublished data). The time course for the alterations of actin fibers corresponds to that for the shear stress-induced increase of G-actin. So, we interpreted that actin fiber disruption into G-actin, which begins within $5 \mathrm{~min}$, triggers alterations in actin fiber distribution.

The most important observation in this study is that the disruption of F-actin not only triggers the redistribution of actin cytoskeleton but also participates in shear stress-induced ET-1 gene expression. In vascular endothelial cells, cytoskeletal structures including actin filaments have been postulated to play a role in maintaining structural integrity and regulating migration, repair, and permeability (25). This study revealed another possible function of endothelial cytoskeleton; the transduction of flow-induced signals to gene expression. This is the first report suggesting that mechanical stimuli induce specific gene expression via alterations in cytoskeletal structures in mammalian cells.

Recently, several reports have presented evidence that actin cytoskeleton is involved in the regulation of expression of genes including collagenase, stromelsin (26), transin (27), and urokinase-type plasminogen activator (15). The expression of these genes has been shown to be induced by cytochalasins-induced actin fiber disruption. Interestingly, the gene expression of tissue plasminogen activator, which is coded in the same gene as urokinase-type plasminogen activator, is shown to be induced by shear stress in endothelial cells (28). Although there is no direct evidence, we can speculate that shear stress-induced expression of both ET-1 and tissue plasminogen activator genes may share common signal transduction pathway(s) mediated by actin fiber disruption.

The mechanisms of actin-mediated ET-1 gene expression remain unknown. One possibility is that ET-1 gene transcription is activated by alterations in nuclear actin cytoskeletal structure. In the process, some actin-binding protein may be involved. For example, cofilin, an actin-depolymerizing pro- tein, binds to G- and F-actin and forms intranuclear actin/cofilin rods in response to various stimuli, including heat shock (29). Shear stress may modulate nuclear actin structure via such actin-binding protein(s) and regulate ET-1 gene transcription. An alternative possibility is that ET-1 mRNA degradation is inhibited by alteration in actin structure. The half-life of ET-1 mRNA is very short (about $15 \mathrm{~min}$ ), and cycloheximide stabilizes the degradation of ET-1 mRNA (30). So, some regulatory protein $(\mathrm{s})$ may be involved in the control of ET-1 mRNA degradation and may be one of the targets of the actinmediated signal transduction pathway.

This study also suggests that microtubules are involved in ET-1 gene expression induced by actin fiber disruption. Recently, Kitazumi et al. (31) reported that treatment with colchicine and vinblastine, another microtubule-disrupting agents, resulted in inhibition of thrombin-induced ET-1 release and accumulation of ET-1 in mitochondrial and microsomal fractions in porcine endothelial cells. They concluded that the impairment of microtubules may cause inhibition of ET-1 secretion rather than suppression of ET-1 synthesis. This observation is not inconsistent with ours because the mechanism of shear stress-and thrombin-induced ET-1 gene expression does not seem to be the same. We can expect that the microtubular system is implicated in ET-1 production in at least two aspects, thrombin-induced secretion and actin-mediated gene expression, although the mechanism is not clear in this study.

Several studies have shown that shear stress can cause increases in intracellular $\mathrm{Ca}^{2+}$ concentration (32) and activation of a $\mathrm{K}^{+}$current (33) in vascular endothelial cells. Moreover, shear stress activates phosphoinositide turnover possibly via phospholipase $\mathrm{C}$ in endothelial cells, resulting in the production of inositol triphosphate and diacylglycerol (34-36), and these second messengers trigger the release of $\mathrm{Ca}^{2+}$ from intracellular pools and the activation of protein kinase $C$, respectively (37). Recently, Frangos and his colleagues have clearly demonstrated that protein kinase $C$ mediates shear stress-induced platelet-derived growth factor gene expression (38) and ET-1 release (39) in cultured endothelial cells. Thus, it is possible that these rapid changes in endothelial cell metabolism may participate in the pathway of shear stress-induced ET-1 gene expression. In our preliminary study, shear stress-induced ET1 gene expression was inhibited by staurosporine, an inhibitor of protein kinase C, but cytochalasins-induced ET-1 gene expression was not. Furthermore, the treatment with staurosporine significantly inhibited shear stress-induced actin fiber disruption (our unpublished data), suggesting that protein kinase $\mathrm{C}$ may be involved in shear stress-induced ET-1 gene expression, at least partially, at the level upstream to actin fiber disruption.

In contrast to these observations, Sharefkin et al. (40) have reported that exposure of endothelial cells to higher shear stress (over $20 \mathrm{dyn} / \mathrm{cm}^{2}$ ) results in suppression of ET-1 production. Frangos and his colleagues have shown that the production of NO induced by shear stress (11) suppresses the release of ET-1 via cGMP and have explained the discrepancy on the basis of difference in CGMP production in response to NO in endothelial cells (39). In addition, difference in actin fiber state in endothelial cells under shear stress may give another explanation. Under high shear stress, endothelial stress fibers appear prominent after as early as $6 \mathrm{~h}$ and the duration of G-actin predominance seems to be much shorter than that under low shear stress (7). Correspondingly, the formation of endothelial stress fibers is positively correlated to the force of local shear 
stress in vivo (8). Considering the observation that actin fiber disruption may mediate ET-1 gene expression, the difference in the kinetics and composition of the actin equilibrial state as well as that in the involvement of NO-induced cGMP increase may explain the discrepancy between the effect of low and high shear stress on ET-1 gene expression. Recent studies of human atherosclerosis and animal models have provided evidence that atheromatous plaque formation tends to occur where shear stress is reduced (41). The increased production of ET-1 in endothelial cells in low shear regions may play a role in the genesis and/or progression of intimal thickening through its potent proliferating activity on vascular smooth muscle cells.

\section{Acknowledgments}

We thank Ms. Chie Fujinami for her excellent technical assistance. We also thank Dr. Mu-En Lee for critical reading of the manuscript and helpful discussion.

This work was supported by grants-in-aid from the Ministry of Education, Science and Culture of Japan, Japanese Heart Foundation, Uehara Memorial Foundation, and Sandoz Gerontological Research Foundation.

\section{References}

1. Dewey, C. F., Jr., S. R. Bussolari, M. A. Gimbrone, Jr., and P. F. Davis. 1981. The dynamic response of vascular endothelial cells to fluid shear stress. $J$. Biomech. Eng. 103:177-185.

2. Langille, B. L., and S. L. Adamson. 1981. Relationship between blood flow direction and endothelial cell orientation at arterial branch sites in rabbits and mice. Circ. Res. 48:481-488.

3. Levesque, M. J., D. Liepsch, S. Moravec, and R. M. Nerem. 1986. Correlation of endothelial cell shape and wall shear stress in a stenosed dog aorta. Arteriosclerosis. 6:220-229.

4. Wong, A. J., T. D. Pollard, and I. M. Herman. 1983. Actin filament stress fibers in vascular endothelial cells in vivo. Science (Wash. DC). 219:867-869.

5. Franke, R. P., M. Grafe, H. Schnittler, D. Seiffge, and C. Mittermayer 1984. Induction of human vascular endothelial stress fibers by fluid shear stress. Nature (Lond.). 307:648-649.

6. Masuda, H., T. Shozawa, S. Hosoda, M. Kanda, and A. Kamiya. 1985. Cytoplasmic microfilaments in endothelial cells of flow loaded canine carotid arteries. Heart Vessels. 1:65-69.

7. Wechezak, A. R., R. F. Viggers, and L. R. Sauvage. 1985. Fibronectin and F-actin redistribution in cultured endothelial cells exposed to shear stress. Lab. Invest. 53:639-647.

8. White, G. E., and K. Fujiwara. 1986. Expression and intracellular distribution of stress fibers in aortic endothelium. J. Cell Biol. 103:63-70.

9. Wechezak, A. R., T. N. Wight, R. F. Viggers, and L. R. Sauvage. 1989. Endothelial adherence under shear stress is dependent upon microfilament reorganization. J. Cell. Physiol. 139:136-146.

10. Rubanyi, G. M., J. C. Romero, and P. M. Vanhoutte. 1986. Flow-induced release of endothelium-derived relaxing factor. Am. J. Physiol. 255:H783-H788.

11. Buga, G. M., M. E. Gold, J. M. Fukuto, and L. J. Ignarro. 1991. Shearstress-induced release of nitric oxide from endothelial cells grown on beads. $H y-$ pertension (Dallas). 17:187-193.

12. Van Grondelle, A., G. S. Worthen, D. Ellis, M. M. Mathias, R. C Murphy, R. J. Striefl, J. T. Reeves, and N. F. Voelkel. 1984. Altering hemodynamic variables influences $\mathbf{P G I}_{2}$ production by isolated lungs and endothelial cells. J. Appl. Physiol. 57:388-395.

13. Frangos, J. A., S. G. Eskin, L. V. McIntire, and C. L. Ives. 1985. Flow effects on prostacyclin production by cultured human endothelial cells. Science (Wash. DC). 227:1477-1479.

14. Yoshizumi, M., H. Kurihara, T. Sugiyama, F. Takaku, M. Yanagisawa, T. Masaki, and Y. Yazaki. 1989. Hemodynamic shear stress stimulates endothelin production by cultured endothelial cells. Biochem. Biophys. Res. Commun. 161:859-864

15. Botteri, F. M., K. Ballmer-Hofer, B. Rajput, and Y. Nagamine. 1990. Disruption of cytoskeletal structures results in the induction of the urokinasetype plasminogen activator gene expression. J. Biol. Chem. 265:13,327-13,334.

16. Ferrua, B., S. Manie, A. Doglio, A. Shaw, S. Sonthonnax, M. Limouse, and L. Schaffar. 1990. Stimulation of human interleukin-1 production and spe- cific mRNA expression by microtubule-disrupting drugs. Cell. Immunol. 131:391-397.

17. Zieba, A., and S. Foner. 1982. Detection coil, sensitivity function, and sample geometry effects for vibrating sample magnetometers. Rev. Sci. Instrum. 53:1851-1854.

18. Blikstad, I., F. Markey, L. Carlsson, T. Persson, and U. Lindberg. 1978. Selective assay of monomeric and filamentous actin in cell extracts, using inhibition of deoxyribonuclease I. Cell. 15:935-943.

19. Hinshaw, D. B., B. C. Armstrong, J. M. Burger, T. F. Beals, and P. A. Hyslop. 1988. ATP and microfilaments in cellular oxidant injury. Am. J. Clin. Pathol. 30:234-238.

20. Auffray, C., and F. Rougeon. 1980. Purification of immunoglobulin heavy-chain messenger RNAs from total myelome tumor. Eur. J. Biochem. 107:303-314.

21. Maniatis, T., E. F. Fritsch, and J. Sambrook. 1982. Molecular Cloning: A Laboratory Manual Cold Spring Harbor Laboratory, Cold Spring Harbor NY. $545 \mathrm{pp}$.

22. Yanagisawa, M., H. Kurihara, S. Kimura, Y. Tomobe, M. Kobayashi, Y. Mitsui, Y. Yazaki, K. Goto, and T. Masaki. 1988. A novel potent vasoconstrictor produced by vascular endothelial cells. Nature (Lond.). 332:411-415.

23. Kurihara, H., M. Yoshizumi, T. Sugiyama, F. Takaku, M. Yanagisawa, T. Masaki, M. Hamaoki, H. Kato, and Y. Yazaki. 1989. Transforming growth factor- $\beta$ stimulates the expression of endothelin mRNA by vascular endothelial cells. Biochem. Biophys. Res. Commun. 159:1435-1440.

24. Suttorp, N., M. Polley, J. Seybold, H. Schnittler, W. Seeger, F. Grimminger, and K. Aktories. 1991. Adenosine diphosphate-ribosylation of G-actin by botulinum $\mathrm{C} 2$ toxin increases endothelial permeability in vitro. J. Clin. Invest. 87:1575-1584.

25. Michael, K., K. Wong, and A. I. Gotlieb. 1989. Endothelial monolayer integrity. Pertubation of F-actin filaments and the dense peripheral band-vinculin network. Arteriosclerosis. 10:76-84.

26. Werb, Z., R. M. Hembry, G. Murphy, and J. Aggeler. 1986. Commitment to expression of metalloendopeptidases, collagenase and stromelysin: relationship of inducing events to changes in cytoskeletal architecture. J. Cell Biol. 102:697-702.

27. Breathnach, R., L. M. Matrisian, M.-C. Gesnel, A. Staub, and P. Leroy. 1987. Sequences coding part of oncogene-induced transin are highly conserved in a related rat gene. Nucleic Acids Res. 15:1139-1151.

28. Diamond, S. L., J. B. Sharef kin, C. Dieffenbach, K. Frasier Scott, L. V. McIntire, and S. G. Eskin. 1990. Tissue plasminogen activator messenger RNA levels increase in cultured human endothelial cells exposed to laminar shear stress. J. Cell. Physiol. 143:364-371.

29. Nishida, E., K. lida, N. Yonezawa, S. Koyasu, I. Yahara, and H. Sakai 1987. Cofilin is a component of intranuclear and cytoplasmic actin rods induced in cultured cells. Proc. Natl. Acad. Sci. USA. 84:5262-5266.

30. Yanagisawa, M., A. Inoue, Y. Takuwa, Y. Mitsui, M. Kobayashi, and T. Masaki. 1989. The human preproendothelin-1 gene: possible regulation by endothelial phosphoinositide turnover signaling. J. Cardiovasc. Pharmacal. 13(Suppl. 5):S13-S17.

31. Kitazumi, K., M. Mio, and K. Tasaka. 1991. Involvement of the microtubular system in the endothelin-1 secretion from porcine aortic endothelial cells. Biochem. Pharmacol. 42:1079-1085.

32. Mo, M., S. G. Eskin, and W. P. Schilling. 1991. Flow-induced changes in $\mathrm{Ca}^{2+}$ signaling of vascular endothelial cells. Effect of shear stress and ATP. Am. $J$. Physiol. 260:H1698-H1707.

33. Olesen, S. P., D. E. Clapham, and P. F. Davies. 1988. Hemodynamic shear stress activates a $\mathrm{K}^{+}$current in vascular endothelial cells. Nature (Lond.) 331:168-170.

34. Bhagyalakshmi, A., and J. A. Frangos. 1989. Mechanism of shear-induced prostacyclin production in endothelial cells. Biochem. Biophys. Res. Commun. 158:33-37.

35. Prasad, A. R. S., R. M. Nerem, C. J. Schwartz, and E. A. Sprague. 1989. Stimulation of phosphoinositide hydrolysis in bovine aortic endothelial cells exposed to elevated shear stress. J. Cell Biol. 109:313A.

36. Nollert, M. U., S. G. Eskin, and L. V. McIntire. 1990. Shear stress increases inositol triphosphate levels in human endothelial cells. Biochem. Biophys. Res. Commun. 170:281-287.

37. Nishizuka, Y. 1986. Studies and perspectives of protein kinase C. Science (Wash. DC). 233:305-312.

38. Hsieh, H.-J., N.-Q. Li, and J. A. Frangos. 1992. Shear-induced plateletderived growth factor gene expression in human endothelial cells is mediated by protein kinase C. J. Cell. Physiol. 150:552-558.

39. Kuchan, M. J., and J. A. Frangos. 1993. Shear stress regulates endothelin1 release via protein kinase $\mathrm{C}$ and CGMP in cultured endothelial cells. Am. $J$. Physiol. 264:H150-H156.

40. Sharefkin, J. B., S. L. Diamond, S. G. Eskin, L. V. McIntire, and C. W. Dieffenbach. 1991. Fluid flow decreases preproendothelin mRNA levels and suppresses endothelin-1 peptide release in cultured human endothelial cells. J. Vasc. Surg. 14:1-9.

41. Glagov, S., C. Zarins, D. P. Giddens, and D. N. Ku. 1988. Hemodynamics and atherosclerosis. Arch. Pathol. Lab. Med. 112:1018-1031. 